Neurosignals 2009;17:242-254

DOI: 10.1159/000231891
Received: April 4, 2009

Accepted after revision: May 26, 2009

Published online: September 30, 2009

\title{
Regulation of Stem Cell Pluripotency and Neural Differentiation by Lysophospholipids
}

\author{
Stuart M. Pitson ${ }^{a, b} \quad$ Alice Pébay ${ }^{c}$ \\ a Division of Human Immunology, Centre for Cancer Biology, SA Pathology, and \\ bSchool of Molecular and Biomedical Science, University of Adelaide, Adelaide, S.A., and \\ 'Centre for Neuroscience and Department of Pharmacology, The University of Melbourne, Parkville, Vic., Australia
}

\section{Key Words}

Ceramide $\cdot$ Lysophosphatidic acid •

Sphingosine-1-phosphate - Lysophospholipid - Stem cells, induced pluripotent $\cdot$ Progenitor cells $\cdot \mathrm{G}$-protein-coupled receptors $\cdot$ Signalling pathways $\cdot$ Neural differentiation

\begin{abstract}
Lysophospholipids are bioactive signalling molecules able to act through the binding of their specific G-protein-coupled receptors to exert pleiotropic effects on a wide range of cells. The most widely studied signalling lysophospholipids are lysophosphatidic acid (LPA) and sphingosine-1-phosphate (S1P). LPA and S1P have been identified to have widespread developmental, physiological and pathological actions in the central nervous system and more recently have been shown to induce biological effects on various stem cell types. This review aims to summarise the current knowledge on LPA and S1P regulation of embryonic and neural stem cell biology.

Copyright $\odot 2009$ S. Karger AG, Base
\end{abstract}

\section{Introduction}

The derivation of human embryonic stem cells (hESCs) in 1998 opened up many exciting new opportunities to further investigate the therapeutic potential of stem cells [1]. Mouse and human ESCs share many properties: they originate from a pluripotent population of cells within the pre-implantation embryo, are karyotypically normal, can be propagated indefinitely (self-renewal) and can differentiate in vitro and in vivo into cells representative of the three embryonic germ layers [for review, see 2]. Although very similar, mouse and human ESCs also show major differences. In particular, the underlying mechanisms of mouse and human ESC maintenance of pluripotency appear to be different [for review, see 3, 4].

Neural stem cells give rise to neural and neuronal progenitor cells. While neural stem/progenitor cells (NS/ PCs) can differentiate into neurons, astrocytes and oligodendrocytes, neuronal progenitor cells, or neuroblasts, differentiate only into neurons. Oligodendrocyte progenitor cells (OPCs) derived from their neural progenitors share properties with both stem cells and progenitor cells and give rise to oligodendrocytes, which allow myelination within the central nervous system (CNS) [for review, see 5]. During development, NS/PCs contribute

\section{KARGER \\ Fax +41613061234 E-Mail karger@karger.ch} www.karger.com
Alice Pébay

Centre for Neuroscience and Department of Pharmacology

The University of Melbourne

Parkville, Vic. 3010 (Australia)

Tel. +61 38344 3988, Fax +61 39349 4432, E-Mail apebay@unimelb.edu.au 
to the neurogenesis of the CNS. In the adult, NS/PCs are located predominantly in neurogenic regions of the CNS, such as the subventricular zone and hippocampus but are also scattered throughout the CNS. NS/PCs can migrate to areas of injury, and also to tumours, and differentiate into neuronal and glial cell types [6], thus are likely to contribute to the repair of damaged tissue. NS/PCs have been extensively studied with the aim of using endogenous and/or donor NS/PCs to replace neurons and restore circuitry in a neurodegenerative microenvironment.

The factors that control the regulation of stem cell survival, proliferation, migration and differentiation are still emerging. Considerable evidence now exists demonstrating the potent effects of lysophospholipids, and in particular lysophosphatidic acid (LPA) and sphingosine-1phosphate (S1P), on the biology of stem cells. This review aims to summarise the current knowledge of the regulation of embryonic and neural stem cell maintenance and differentiation by LPA and S1P.

\section{Lysophospholipid Metabolism and Signalling}

Lysophospholipids are simple phospholipids with only a single O-acyl chain. Despite their generally simple structure, lysophospholipids appear to be involved in regulating a wide array of cellular processes through their functions as extracellular ligands for cell surface receptors and as intracellular second messengers. Biological effects have been described for a wide variety of phospholipids and lysophospholipids, including sphingosylphosphorylcholine, platelet-activating factor, alkyl glycerol phosphate and cyclic phosphatidic acid. The most extensively studied bioactive lysophospholipids, however, are LPA and S1P.

\section{LPA and S1P Metabolism}

Various pathways exist to facilitate the formation of LPA. Most of the LPA in serum and plasma appears to arise from the activity of autotaxin, a secreted lysophospholipase D that generates LPA from lysophospholipids such as lysophosphatidylcholine, lysophosphatidylserine or lysophosphatidylethanolamine released from activated platelets [7]. LPA can also be generated extracellularly from the deacylation of phosphatidic acid by the activity of secreted phospholipases $A_{1}$ and $A_{2}$ [for review, see 8]. A similar route for LPA generation catalysed by intracellular phospholipases $A_{1}$ and $A_{2}$ also occurs within cells which appears responsible for the high levels of LPA stored in platelets [8]. Although less abundant, LPA can also arise from phosphorylation of monoacylglycerol by monoacylglycerol kinase [9] or acylation of glycerol 3phosphate by glycerol 3-phosphate acyltransferase [10].

In contrast to that of LPA, generation of S1P occurs by only a single route via the phosphorylation of sphingosine by the sphingosine kinases (SphKs), of which 2 have been identified in mammals (SphK1 and SphK2). Growth factor or cytokine-induced activation of SphK1 results in re-localisation of this enzyme to the plasma membrane where it appears to be the major source of S1P under these conditions [11, 12]. Notably, however, knockout mouse studies indicate that both SphK1 and SphK2 may play an equivalent role in maintaining plasma S1P levels $[13,14]$. The cellular source of circulating S1P has been the subject of considerable recent debate with studies suggesting platelets [15], erythrocytes [16] and vascular endothelial cells [17] as major sources of S1P. Release of this intracellular S1P has been thought to be mediated by ATP-binding cassette $(\mathrm{ABC})$ transporters, specifically $\mathrm{ABCC} 1$ in mast cells [18], although recent zebrafish genetic studies have identified a novel sphingolipid transporter, spinster 2 (also called two of hearts) that appears to also function in this manner $[19,20]$. Interestingly, SphK1 can also be secreted where it may generate S1P extracellularly, although this appears likely to generate only a minor proportion to the pool extracellular S1P [21-23].

\section{Cellular Signalling by LPA and S1P}

Plasma levels of LPA and S1P dramatically increase after injury due to their (or their precursor's) release from activated platelets, leading to a variety of responses in tissues, including in the CNS. These lysophospholipids have effects on most cells, eliciting responses to alter proliferation, survival, migration and differentiation. Many of these effects are mediated through widely expressed Gprotein-coupled receptors (GPCRs) for these lysophospholipids [24]. Five $\mathrm{S} 1 \mathrm{P}$ receptors $\left(\mathrm{S}_{1} \mathrm{P}_{1-5}\right)$ have been established, while up to 7 receptors for LPA have been identified, including $\mathrm{LPA}_{1-5}$, and the more recently discovered GPCRs P2Y5 [25-27] and GPR87 [28]. A further GPCR, $\mathrm{P} 2 \mathrm{Y} 10$, has also been recently proposed to have both S1P and LPA as ligands [29], although further characterisation of this receptor is required.

The S1P and LPA receptors are differentially expressed and linked to different $G$ proteins, allowing these lysophospholipids to elicit a variety of cell-specific responses through the activation of classic $G_{i}, G_{q}, G_{12}$, and possibly $\mathrm{G}_{s}$, signalling pathways $[24,30,31]$. Depending on the receptors present, many of the signalling effects of LPA 
Fig. 1. General signalling pathways regulated by S1P and LPA. Association of S1P and LPA receptors with G-protein families and the general signalling pathways regulated are indicated.

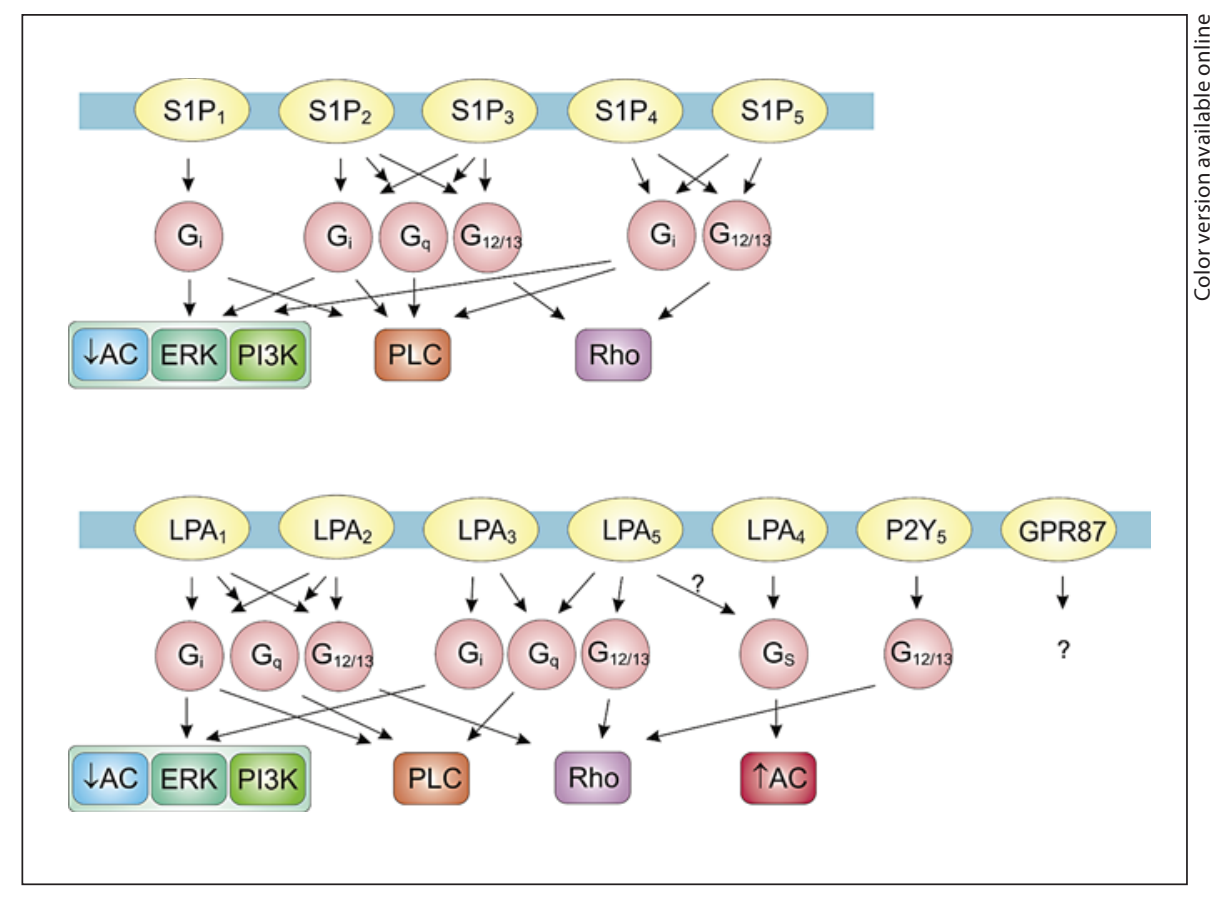

and S1P are mediated through the activation of extracellular signal-regulated kinases 1/2 (ERK1/2), phospholipase C (PLC), and small GTPases, as well as through calcium mobilisation, and the activation or inhibition or adenylate cyclase (AC; fig. 1). While many of the downstream pathways leading from each individual lysophospholipid receptor have been elucidated, it is becoming increasingly clear that lysophospholipid-regulated biological outcomes are commonly dependent on integration of signals from multiple lysophospholipid receptors as well as their well-established cross-talk with cytokine and growth factor receptors, such as the platelet-derived growth factor (PDGF) and epidermal growth factor (EGF) receptors [22, 32-35]. Thus, the challenge remains to understand how the integration of these divergent signalling pathways leads to the fine control of cellular processes.

In addition to GPCR-mediated signalling, LPA can also act as an intracellular second messenger via its association with the nuclear transcription factor, peroxisome proliferator-activated receptor $\gamma$ (PPAR $\gamma$ ) [36]. PPAR $\gamma$ regulates genes involved in vascular inflammation, adipocyte differentiation, as well as glucose and fatty acid metabolism [37], and binding of LPA appears to stimulate its transcriptional activity. An intracellular second messenger role for S1P has long been proposed, but to date no direct intracellular targets of S1P have been identified and remains a future challenge.

\section{LPA/S1P Signalling in Embryonic Stem Cells}

\section{LPA/S1P Signalling in Mouse Embryonic Stem Cells}

Mouse ESCs (mESCs) express LPA and S1P receptors with variation between $\mathrm{mESC}$ lines which might reflect differences in the strains used, or in the experimental conditions used to derive or maintain mESCs [38-40]. All 5 S1P receptors are expressed in R1 mESCs [39], while $\mathrm{S}_{4} \mathrm{P}_{4}$ is not found to be expressed in CGR8 and ES-D3 mESCs [40]. $\mathrm{LPA}_{1-3,5}$ have been described in R1 mESCs $[39,41]$. Both LPA and S1P are positive regulators of mESC proliferation with data showing that LPA increases the mESC proliferation rate [41] and that antagonists of $1 \mathrm{P}_{1-2}$ inhibit basal mESC proliferation [40]. In mESCs, the main pathway allowing maintenance of pluripotency appears to be through the activation of the JAK/STAT3 pathway, leading to the transcription of self-renewal genes [for review, see 42]. Although demonstrated in other cell types [43,44], stimulation of STAT3 by either LPA or S1P in mESCs has not yet been described. However, Todorova et al. [41] recently demonstrated that LPA induces $\mathrm{mESC}$ proliferation through the PLC/calcium mobilisation-induced expression of $c-m y c$. As both LPA and S1P stimulate ERK1/2 phosphorylation [40, 45], a pathway involved in $\mathrm{mESC}$ proliferation but also differentiation $[42,46]$, these bioactive lipids can also potentially be regulators of $\mathrm{mESC}$ differentiation. Indeed, in parallel to 
its effect on proliferation, S1P promotes mESC-embryoid body (EB) differentiation towards cardiomyocytes [47]. However, ERK1/2 activation by LPA induces the expression of the early gene $c$-fos which would suggest a role in maintenance rather than in differentiation [45]. JNK1/2 phosphorylation is also stimulated by LPA, yet its biological significance remains to be characterised [45]. Since pharmacological tools for blocking/stimulating specific aspects of lysophospholipid signalling are only now becoming commercially available, little is currently known of LPA/S1P receptor subtype-specific effects in mESCs. Yet activation of the ERK1/2 pathway by S1P seems to be mediated by $\mathrm{S}_{1} \mathrm{P}_{5} / \mathrm{G}_{\mathrm{i}}$ and not involved in the regulation of basal mESC proliferation [40].

Endogenous sphingolipid metabolism is likely to play a role in ESC maintenance and differentiation. Ceramide is a precursor of sphingosine and its levels are closely related to those of S1P. Ceramide induces the binding of prostate apoptosis response protein 4 (PAR-4) to the atypical protein kinase $\mathrm{C} \zeta$ [48], an effect responsible for ceramide-induced apoptosis in cells showing elevated levels of PAR-4. As S1P antagonises ceramide-induced apoptosis [49], it is likely to protect any cell type with high levels of PAR-4 from ceramide-induced apoptosis [50]. In mESCs, the endogenous levels of ceramide are low, increase upon EB formation until the early phase of NS/PC differentiation and finally decrease during the following steps of neural differentiation [48]. Furthermore, there is an asymmetric distribution of PAR- 4 and endogenous ceramide levels in cells within EBs, with PAR-4 being more expressed within the ESC of the EBs [48]. This restrictive partitioning suggests a specificity of apoptosis by ceramide on ESCs while the NS/PCs further proliferate or differentiate [48], which, as a consequence, reduces the amount of ESCs and enriches EBs in NS/PCs [51]. EBs and neurospheres are often considered a better source of cells than undifferentiated ESCs for stem cell engraftment, as they have less potential to induce the formation of teratomas, due to their reduced differentiation potential. However, the inoculation of EBs or neurospheres in vivo can always be contaminated by less committed cells. Thus, a selective-induced apoptosis of the less committed cells within EBs by ceramide has the potential of preventing teratoma formation and enriching EBs in NS/PCs when injected in vivo [51].

\section{LPA/S1P Signalling in Human Embryonic Stem Cells}

Some of the most potent protocols for long-term hESC culture require the presence of a feeder cell layer of mouse embryonic fibroblasts (MEFs) in serum or Knockout
Serum Replacement ${ }^{\circledR}$ media (hESC media). hESCs and MEFs have different profiles of lipid content and basal sphingolipid metabolism, with sphingosine, S1P, sphingomyelin and glucosylceramide found at lower levels in hESCs than in MEFs [52], suggesting that MEFs may release bioactive sphingolipids in the culture medium. This could account for some of the MEF-mediated effects on hESCs. hESCs are target cells of LPA and S1P, as their receptors $\mathrm{LPA}_{1-5}$ and $\mathrm{S}_{1} \mathrm{P}_{1-3}$ have been found to be expressed on various hESC lines [53-55]. No biological effect of LPA on hESCs has been described so far [53], and contrary to what was described in mESCs, we have not observed modification of the intracellular calcium concentration in hESCs treated with LPA [Wong and Pebay, unpublished data]. While S1P does not substantially prevent spontaneous differentiation of hESCs, its co-incubation with PDGF allows the long-term maintenance of hESCs in vitro in the absence of serum and in the presence of MEFs [53]. This long-term maintenance of hESCs by S1P and PDGF is at least $\mathrm{G}_{\mathrm{i}^{-}}$, ERK1/2- and SphK-dependent [53]. S1P and PDGF appear to act on the different levels of hESC maintenance: pluripotency, proliferation and survival, through the activation of specific signalling pathways $[53,56]$. Exposure to S1P results in sustained activation of the ERK1/2 pathway (at least $5 \mathrm{~h}$ ) but not the PI3K/Akt pathway, while PDGF stimulates both ERK1/2 and PI3K/Akt pathways [56, 57]. Interestingly, although the Smad2/3 pathway appears to be essential to hESC maintenance in different culture systems [58], neither S1P nor PDGF modifies Smad2 phosphorylation even after $2 \mathrm{~h}$ of incubation [56]. We have also found that S1P and PDGF stimulate the phosphorylation of p38 and, less potently, JNK1/2, although the physiological consequences of this have not yet been established (fig. 2). S1P stimulates proliferation and inhibits apoptosis and necrosis of hESC when added to a MEF-conditioned medium supplemented in basic fibroblast growth factor (bFGF) [54]. As these data were obtained in the presence of bFGF, whether this effect is indeed independent of bFGF remains to be assessed. The sole application of S1P is anti-apoptotic to hESCs, an effect abolished by inhibition of the ERK1/2 or PI3K/Akt pathways, but not altered by the inhibition of the mammalian target of rapamycin [56]. Since S1P does not activate the PI3K/Akt pathway in these cells, inhibition of this pathway leading to a prosurvival effect is probably linked to its basal activation independent of S1P. Microarray analysis showed that S1P modifies the expression of a large number of genes $(>1,000)$ in hESCs with an up-regulation of anti-apoptotic, cell cycle progression and cell adhesion genes, and 


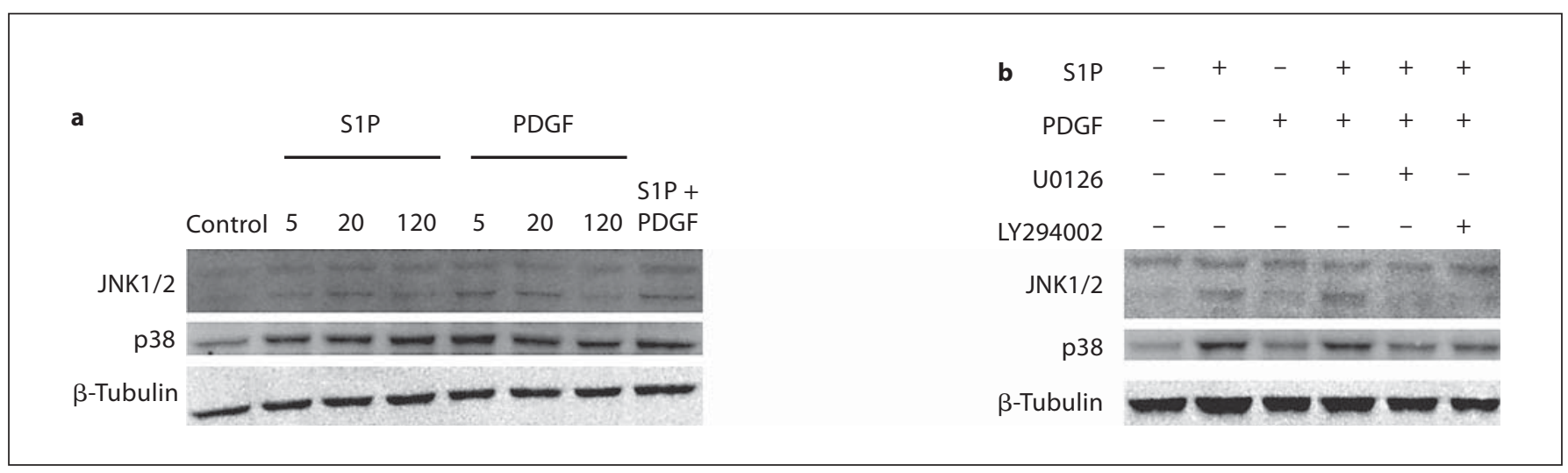

Fig. 2. S1P and PDGF induce the phosphorylation of JNK1/2 and p38 in hESC ( $\mathrm{n}>3)$, in an ERK1/2-dependent manner. a S1P (10 $\mu \mathrm{M})$ and PDGF $(20 \mathrm{ng} / \mathrm{ml})$ stimulate JNK1/2 and $\mathrm{p} 38$ phosphorylation in hESC. 5, 20, $120=$ Time of activation in minutes. $\mathbf{b}$ Coincubation of S1P + PDGF (20 min) induces phosphorylation of
JNK1/2 and p38 in hESC. JNK1/2 and p38 phosphorylation are regulated by ERK1/2 as U0126 reduces JNK and p38 phosphorylation induced by S1P/PDGF. The membranes were stripped and re-blotted with $\beta$-tubulin as a loading control. down-regulation of pro-apoptotic genes, suggesting that $\mathrm{S} 1 \mathrm{P}$ is an important factor in hESC maintenance [57]. However, S1P also down-regulates pluripotency genes in particular nanog and Oct-4 [57], which suggests that S1P by itself is not sufficient to maintain hESCs undifferentiated. In an attempt to identify compounds within hESC media that benefit hESC maintenance, Garcia-Gonzalo and Belmonte [59] identified that albumin-associated lipids present in media stimulate hESC renewal, yet did not observe the obvious effect of either LPA or S1P on hESCs, which confirms our findings that sole application of S1P or LPA does not maintain hESCs in culture [53].

From the studies discussed above it is clear that LPA and S1P have different effects on mouse and human ESCs. This is not surprising as the signalling pathways involved in maintenance or differentiation in both cells are different. Indeed, in both cell types S1P stimulates the ERK1/2 pathway, a signalling pathway generally involved in the differentiation of mESCs and in the maintenance of hESCs. Whether this reflects a variation between species or a difference in the cells used to generate ESC lines needs to be further determined.

Ceramide, while not a lysophospholipid, is a precursor to S1P and has been observed to have effects on hESCs, although the true role of this lipid in hESC regulation remains somewhat controversial. Indeed, as is observed in the mouse, undifferentiated hESCs within EBs are sensitive to ceramide and undergo apoptosis following incubation with ceramide [51]. Another recent study showed, however, that colonies of undifferentiated hESCs are re- sistant to ceramide-induced apoptosis while more differentiated hESCs within the colonies are not [60]. Indeed, the authors of this latter study exploited this characteristic to successfully maintain hESCs in culture by adding ceramide [60]. Thus, in 2 different assays using hESCs, the sensitivity towards ceramide appeared to be different. These contradictory results might be due to the different culture systems used in these studies, and it is tempting to speculate that it may reflect a variation in ceramide metabolism, including cellular SphK activity, depending on the environment in which hESCs are cultivated.

\section{Induced Pluripotent Stem Cells}

In 2006, a novel technology was developed whereby 4-6 genes are introduced into an adult somatic cell resulting in its reprogramming into an 'embryonic-like' or pluripotent cell, named induced pluripotent stem cell (iPS) [61-66]. Derivation of human iPS from diseased cells allows the generation of hESC-like cells, without having to derive hESCs from fertilised oocytes or cloning. As iPS can be generated from biopsies, these cells open new avenues to study diseases, and overcome rejection if injected into the source patients. In theory, ESCs and iPSs are able to differentiate into all cell types of the body. For this reason, they generate great hope for human therapy/regenerative medicine, as well as being useful as a human cell model for drug discovery. Our data indicate that iPSs express the mRNA for $\mathrm{S1P}_{1,3}$ and $\mathrm{LPA}_{1-4}$, which differs from hESC expression (fig. 3 ). This might suggest different roles of S1P and LPA in these cells than in hESCs 


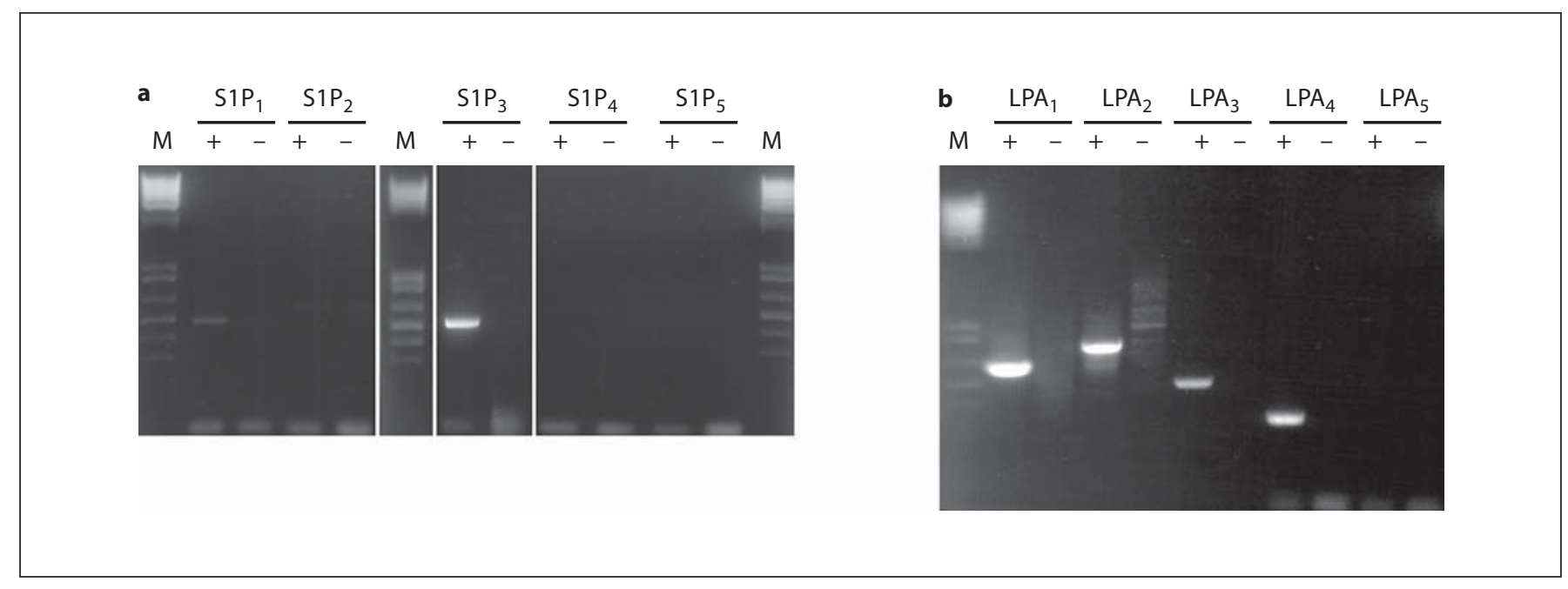

Fig. 3. S1P and LPA receptor $m R N A$ are expressed in human iPS RT-PCR for S1P (a) and LPA (b) receptors with (+) or without (-) RT in human iPS. $\mathrm{M}=\mathrm{DNA}$ ladder. Expected sizes: $\mathrm{S}_{1} \mathrm{P}_{1} 480 \mathrm{bp}$; ${\mathrm{S} 1 \mathrm{P}_{2}}_{2} 502$ bp; S1P 505 bp; S1P 701 bp; S1P 460 bp; LPA $_{1} 621$ bp;
$\mathrm{LPA}_{2} 775$ bp; $\mathrm{LPA}_{3} 482 \mathrm{bp} ; \mathrm{LPA}_{4} 318$ bp, and LPA 185 bp. RT-PCR were performed as described by Pebay et al. [53] and Dottori et al. [55]. Data are representative results of independent experiments performed on 2 different iPS cell lines: hiPS1 and ESCL4. or be a consequence of a non-total reprogramming of fibroblasts into iPSs. However, their biological effects in iPSs have not yet been investigated. These data also indicate phenotypic variation between iPSs and hESCs.

\section{LPA/S1P Signalling in Neural Stem/Progenitor and Oligodendrocyte Progenitor Cells}

\section{LPA/S1P Receptor Expression in Neural Stem/}

Progenitor and Oligodendrocyte Progenitor Cells

Neural Stem/Progenitor Cells

S1P and LPA receptors are expressed in neuroblasts and NS/PCs and both ligands display a range of effects on these cells. It seems, however, that receptor expression varies between species, developmental stage and origin of the NS/PCs. Rat embryonic hippocampal NS/PCs express $\mathrm{S}_{1} \mathrm{P}_{1-3,5}$ and undetectable levels of $\mathrm{S}_{1} \mathrm{P}_{4}$ [67] and immortalised rat embryonic hippocampal progenitor H197 cells express $\mathrm{LPA}_{1,4}$ [68]. Mouse and rat embryonic forebrain NS/PCs express all $5 \mathrm{~S} 1 \mathrm{P}$ receptors $\left(\mathrm{S}_{1} \mathrm{P}_{1-5}\right)$, although quantitative PCR showed some variation in the expression of these receptors $[69,70]$. Indeed, mouse embryonic forebrain NS/PCs predominantly express $\mathrm{S}_{1} \mathrm{P}_{1,2}$, lower levels of $\mathrm{S} \mathrm{P}_{3}$ and weak levels of $\mathrm{S}_{4} \mathrm{P}_{4,5}$ [70], while rat embryonic forebrain NS/PCs predominantly express $\mathrm{S}_{1} \mathrm{P}_{1}$, lower levels of $\mathrm{S}_{1} \mathrm{P}_{2,4}$ and weak levels of $\mathrm{S}_{1} \mathrm{P}_{3,5}$ [69]. Rat embryonic forebrain NS/PCs also express $\mathrm{LPA}_{2>1,3}$, but no data are available on the expression of other LPA receptors [69]. Seven-day postnatal mouse forebrain NS/ PCs express $\mathrm{LPA}_{1-3}$ [71]. In the human, hESC-derived $\mathrm{NS} / \mathrm{PCs}$ express $\mathrm{LPA}_{1-5}$ and $\mathrm{S}_{1} \mathrm{P}_{1,3}$ (fig. $4 \mathrm{a}$ ), although their relative abundance is not yet known [55], and hESC-derived neuroepithelial cell line (NEP) - a stable line that resembles hESC-derived NS/PCs and grows under adherent conditions [72] - expresses $\mathrm{LPA}_{1,2,4>5}, \mathrm{~S} \mathrm{P}_{1-3>5}$ and undetectable levels of $\mathrm{LPA}_{3}$ and $\mathrm{S}_{4} \mathrm{P}_{4}$ [73].

From these studies it is clear that differential receptor expression can partially explain the variation in cellular effect of LPA or S1P on NS/PCs, as these different receptors signal through different $G$ proteins. In particular, $\mathrm{LPA}_{4,5}$ are hypothesised to stimulate $\mathrm{G}_{\mathrm{s}}$ as they stimulate adenylate cyclase signalling in some cell types [38, 74, 75], thus their absence would potentially remove the possibility of $\mathrm{G}_{\mathrm{s}} / \mathrm{cAMP}$ production. The absence of other receptor subtypes might have fewer consequences on cell signalling. For instance, $\mathrm{S}_{4} \mathrm{P}_{4}$ or $\mathrm{LPA}_{3}$ show redundancy of signalling with other receptors; thus, their absence (as observed in human NEP) is likely not to be associated with a lack of signalling.

Oligodendrocyte Progenitor Cells

As observed in NS/PCs, data obtained in OPCs suggest variation in receptor expression between species. $\mathrm{LPA}_{1}$ and $\mathrm{S1P}_{5>1-3}$ are expressed by embryonic and adult rodent OPCs [76-79], while human fetal OPCs express 


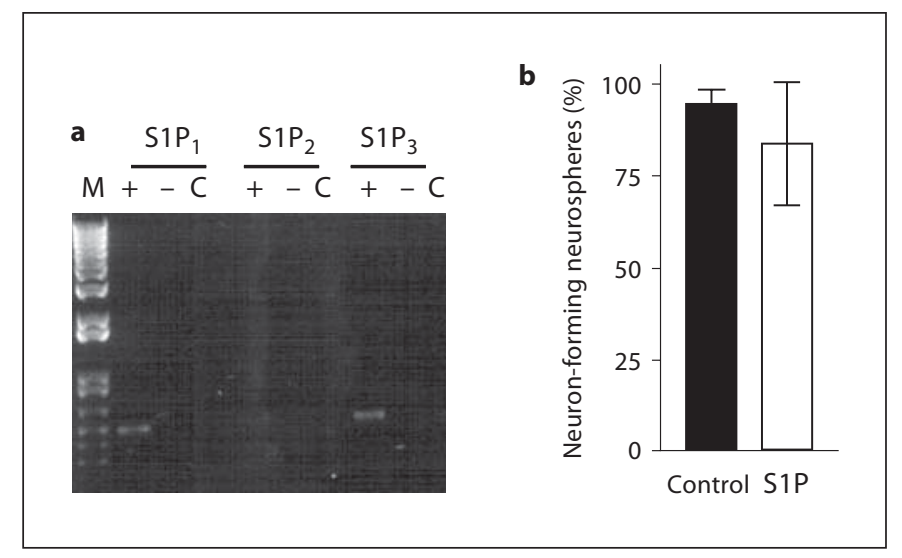

Fig. 4. S1P receptor mRNA expressed in hESC-derived NS/PC and S1P does not inhibit their neuronal differentiation. a RT-PCR for S1P receptors with (+) or without (-) RT in hESC-derived neurospheres. $\mathrm{M}=\mathrm{DNA}$ ladder; $\mathrm{C}=$ control $\mathrm{PCR}$. Expected sizes as in the legend to figure 3. Data are representative results of at least 3 independent experiments. b Quantification of neuron-forming neurospheres from hESC-derived neurospheres plated onto laminin and incubated in the absence (control) or in the presence of S1P $(10 \mu \mathrm{M})$ for 5 days. Quantification was done by counting the number of spheres from which neuronal outgrowth was observable. In some cases, neurospheres failed to attach, independent of the treatments, and these floating neurospheres were not taken into consideration for quantification. Data are expressed as the means \pm SEM from at least 3 independent experiments. $p>0.05$ $(\mathrm{n}=3)$ by $\mathrm{t}$ test.

high levels of $\mathrm{S}_{1} \mathrm{P}_{1}$, low levels of $\mathrm{S}_{1} \mathrm{P}_{5>3}$ and undetectable levels of $\mathrm{S1P}_{4}$ [80]. LPA receptor expression in human OPCs has not yet been described. In a mESC-derived cell line hypothesised to be OPCs, due to the expression of the marker A2B5 (which is however also found on other glial cells), $\mathrm{S}_{1} \mathrm{P}_{1}$ was also shown to be expressed [50].

\section{LPA/S1P Signalling in the Developing CNS}

In the developing central and peripheral nervous systems, LPA and S1P have been shown to target endothelial cells, microglia [81, 82], astrocytes [83-87], oligodendrocytes [88], Schwann cells [89], neurons [90] and stem cells $[30,53,55,91]$. Studies suggest that during development, LPA stimulates neuronal differentiation of embryonic cortical neuroblasts, neural progenitors and early cortical neurons $[68,71,92,93]$. LPA can be produced and released by post-mitotic neurons, oligodendrocytes [77, 94] and Schwann cells $[91,95]$, and it is now hypothesised that LPA is an important factor for cortical neurogenesis by 'guiding' the migration and differentiation of neuroblasts, then neurons, from the ventricular zone to their final destina- tion during development $[92,93,95,96]$. Data also suggest a local synthesis and release of S1P within the CNS. For example, cerebellar astrocytes have been shown to release S1P in response to basic fibroblast growth factor (bFGF), NS/PCs express SphK1 and SphK2, and glutamate induces the release of high levels of S1P by OPCs $[67,78,97]$. Little is known of the effect of S1P in neuroblasts and NS/PCs, and reports on the effect of LPA often appear contradictory. Indeed, effects vary between NS/PCs of embryonic or adult origin, and between species, which might either reflect fundamental differences in LPA signalling between species or may simply be due to the examination of different cell populations and/or variation in the LPA concentration used. Yet, the effects of S1P and LPA on neural progenitor cells have been described on differentiation, proliferation, morphological changes and migration.

\section{Neuroblasts}

LPA stimulates neuronal differentiation of mouse cerebral cortex neuroblasts, NS/PCs and early neurons, possibly via $L P A_{1} / G_{i}$ proteins $[92,93,95]$. Proliferation of mouse cerebral cortex neuroblasts in response to LPA was observed in vitro but not retrieved in vivo [92]. Morphological rearrangements are also induced by LPA. These include cell rounding, membrane retraction, formation of retraction fibres and cluster compaction [92, 95, 98, 99], through $\mathrm{LPA}_{1}$-mediated Rho activation [95]. Notably, no comparable effects were observed in these cells with S1P [95]. Interestingly, LPA also depolarises mouse embryonic cortical neuroblasts by increasing ionic conductances [100], which in turn activates the electrical responses preceding GABA and L-glutamate signalling [100].

\section{Neural Stem/Progenitor Cells}

$\mathrm{NS} / \mathrm{PCs}$ can be maintained in culture as neurospheres in the presence of bFGF and EGF $[101,102]$. Further differentiation of NS/PCs into mature neurons and glial cell types can be achieved by growth of the NS/PCs on laminin or fibronectin substrates, respectively, and culturing without growth factors. LPA inhibits mouse embryonic cortical NS/PC growth as neurospheres, at least partially via transiently increasing cell death [93]. Yet, in neurospheres from 7-day postnatal mice, LPA induces clonal generation of neurospheres through activation of $\mathrm{LPA}_{1}$, supports neurosphere growth and proliferation through $\mathrm{LPA}_{1,3}$ [71], and in rat cortical NS/PCs, LPA stimulates $(<1 \mu \mathrm{M})$ or inhibits (at concentrations of $>1 \mu \mathrm{M}$ ) proliferation, while also promoting neuronal differentiation and migration [103]. However, in human NS/PCs derived 
from hESCs, pathological concentrations of LPA $(10 \mu \mathrm{M})$ inhibits neurosphere formation without modifying proliferation or apoptosis [55], while LPA and S1P $(<0.1 \mu \mathrm{M})$ stimulate cell growth of NEP probably through $G_{i}$ transactivation of EGF and activation of the ERK1/2 pathway [73]. In rat hippocampal NS/PCs, LPA does not affect proliferation, probably due to the fact that it does not activate ERK1/2 in these cells. LPA does, however, induce morphological rearrangements in these cells, an effect dependent on Rho-associated kinases [67], while S1P stimulates their proliferation through $\mathrm{G}_{\mathrm{i}}$-dependent ERK1/2 activation, increases telomerase activity, induces Rho-mediated morphological changes, and increases expression of bFGF and Egr-1 (early growth response-1) [67]. Furthermore, LPA promotes neuronal differentiation of mouse embryonic cortical NS/PCs [93] and of the immortalised embryonic hippocampal progenitor cell line H19-7, possibly through $\mathrm{G}_{\mathrm{s}}$ and cAMP signalling [68]. LPA, however, inhibits hESC-derived NS/PC neuronal differentiation, while maintaining glial differentiation [55], a reversible, receptor-mediated effect (at least by $\mathrm{LPA}_{1 / 3}$ ) that is dependent on PI3K/Akt and Rho/ROCK [55]. In NEP, in addition to stimulating cell growth, LPA and S1P also induce reversible cell rounding through Rho/ROCK [73], while no obvious effect of S1P on hESCderived NS/PC differentiation was observed (fig. 4b). Thus, although similar, hESC-derived NS/PCs and NEP do not show similar responses to LPA and S1P. Further work is required to examine if these apparent differences are real, or are simply reflective of the different conditions under which these studies have been performed.

\section{LPA/S1P Signalling in Oligodendrocyte Progenitors}

One essential aspect of oligodendrocyte maturation is the formation of processes involved in the migration of OPCs and the myelination of neurons [104]. LPA and S1P both target OPCs and inhibit this aspect of oligodendrocyte maturation. Through the activation of the Rho pathway by $\mathrm{LPA}_{1}$ and $\mathrm{S}_{1} \mathrm{P}_{5}$, respectively, LPA and S1P induce process retraction [76, 77]. LPA and S1P appear to activate different signalling pathways in OPCs as (i) only S1P induces membrane ruffling [76], and (ii) S1P inhibits the integrin-driven migration of OPCs through $\mathrm{S}_{\mathrm{P}} / \mathrm{Rho}$ [78]. $\mathrm{S}_{5} \mathrm{P}_{5}$ is preferentially expressed in the oligodendrocytic lineage [79] and is responsible for the S1P inhibition of rodent OPC migration [78]. In human OPCs, the S1P analogue FTY720 regulates S1P receptor expression, leading to temporally regulated biological effects: FTY720 first induces process retraction and inhibition of differentiation through the $\mathrm{S}_{1} \mathrm{P}_{5,3} / \mathrm{Rho}$ pathway, and secondly stimulates process extension, cell survival in a $\mathrm{S}_{1} \mathrm{P}_{1} / \mathrm{ERK} 1 / 2$-dependent manner $[80,105$, 106].

Studies also indicate cross-talk between neurotrophin and S1P signalling in OPCs. Neurotrophin-3 (NT-3) stimulates the proliferation and survival of OPCs via the phosphorylation of cAMP-response element-binding protein (CREB) [107], a signalling pathway that is partially controlled by SphK [94]. S1P also stimulates CREB phosphorylation, an effect mediated by the protein kinase C/ERK pathway [94]. As dihydro-S1P mimics the effect of S1P in OPCs, it was proposed that S1P acts through the binding of its specific receptors after its release from cells following NT-3 activation of SphK1 [94]. Lastly, Bieberich and colleagues identified a small subpopulation of NS/PCs, named NPC2 cells, that have high levels of PAR-4. Notably, S1P rescues these cells (which may be OPCs) from ceramide-induced apoptosis, probably through $\mathrm{S}_{1} \mathrm{P}_{1}$ [50] providing further evidence that the balance between ceramide and S1P may be an important influence on stem cell biology and differentiation protocols [50, 51, 108-110].

\section{LPA/S1P Signalling in the Injured CNS through \\ Neural Stem/Progenitor Cells}

To date, little has been examined regarding the effects of LPA and S1P in the adult CNS, despite data strongly suggesting that neural responses to LPA and S1P stimuli are likely to significantly influence the amount of ensuing damage or repair. Following events which damage the blood-brain barrier, 'LPA-like activity' is increased within the cerebrospinal fluid and levels of LPA within the CNS are hypothesised to increase up to $10 \mu \mathrm{M}[91,111-$ 113]. Normally undetectable, levels of the LPA-producing enzyme autotaxin increase in astrocytes neighbouring a lesion of the adult brain [114], supporting a role for LPA in brain injury responses. LPA injections into mouse brain induce astrocyte reactivity at the site of the injury [115], while in the spinal cord following trauma, LPA induces neuropathic pain and demyelination [116-121]. LPA can stimulate astrocytic proliferation $[87,111]$ and, depending on its concentration, it can promote death of hippocampal neurons by apoptosis $(1 \mu \mathrm{M})$ or by necrosis $(10 \mu \mathrm{M})$ [122]. Moreover, LPA mediates microglial activation [81] and is cytotoxic to the neuromicrovascular endothelium [123]. Furthermore, data suggest an important role of LPA and S1P on embryonic and adult NS/PC differentiation following trauma. For example, our studies with embryonic derived-NS/PCs show that a pathological concentration of LPA $(10 \mu \mathrm{M})$ inhibits neuronal dif- 
ferentiation of human NS/PCs, while lower concentrations do not [55]. This suggests that the presence of high levels of LPA within the CNS following an injury inhibits endogenous neuronal regeneration and maintains gliogenesis. S1P levels also increase in the CNS following spinal cord injury, brain injury or disruption of the bloodbrain barrier $[69,70,113,124]$. Following brain or spinal cord injury, S1P signalling is reported to mediate migration of NS/PCs towards the lesion sites [69, 70]. Indeed, $\mathrm{S} 1 \mathrm{P}$ is a potent chemoattractant of NS/PCs and induces the migration of endogenous NS/PCs towards brain-injury sites [70], and of transplanted NS/PCs toward spinal cord injury sites via $G_{i}$ and the Rho pathway [69]. Exogenous NS/PC migration is also induced by LPA but to a lesser extent [69].

LPA and S1P are also modulators of various cancers and can influence cancer stem cell biology. In humans, the CD133-positive cancer stem cells which represent a subpopulation of cells within glioblastoma [125] are highly tumorigenic, show resistance to chemotherapy [126] and are responsive to LPA and S1P. These cells express all S1P receptors and at least $\mathrm{LPA}_{1-3}$, with high levels of $\mathrm{LPA}_{1,3}$ and $\mathrm{S} 1 \mathrm{P}_{1,2,4}$ in vitro and high levels of $\mathrm{LPA}_{1}$ and $\mathrm{S}_{1,2}$ in vivo, a variation in receptor expression that might be due to a paracrine regulation within the tumour [125]. Notably, both SphK1 and autotaxin are elevated in glioblastomas [127-131], and their products, S1P and LPA, have been shown to stimulate migration of these cells [131-133], which is likely to be responsible, at least in part, for the tumour invasiveness of the cancer stem cells [125].

\section{Conclusions}

While still an emerging area of research, there is now considerable evidence pointing to important roles of lysophospholipids in the regulation of stem cell biology. As described above, LPA and S1P have been shown to modulate proliferation, survival, differentiation and migration of embryonic and neural stem cells. This diverse array of biological effects clearly illustrates the complexity of lysophospholipid signalling. Indeed, these lysophospholipids can act both intracellularly and extracellularly, can bind to multiple receptors coupled to various $G$ proteins to directly activate or inhibit various signalling pathways, and also cross-talk with other cy tokine and growth factor receptors. It is apparent that stem and progenitor cells express different lysophospholipid receptors not only depending on their source of origin, but also on the conditions used for their isolation and/or culture. This illustrates the difficult task ahead of transposing to the human system the data obtained in both developing or adult animals and cultured stem and progenitor cells.

\section{Acknowledgements}

This work was supported by a Senior Research Fellowship (to S.M.P.), Project Grants 454723 and 508097 from the National Health and Medical Research Council of Australia, the Fay Fuller Foundation and Friedreich Ataxia Research Association. The authors thank Ms. Kathryn C. Davidson, Aude Pébay and Jessie Leung, for their technical assistance in work that lead to the data presented in figures 1,2 and 4. The authors thank Dr. Paul Verma, Dr. Jun Liu and Prof. James Thompson for providing iPS cell lines.

\section{References}

1 Thomson JA, Itskovitz-Eldor J, Shapiro SS, Waknitz MA, Swiergiel JJ, Marshall VS, Jones JM: Embryonic stem cell lines derived from human blastocysts. Science 1998;282: 1145-1147.

2 Verfaillie CM, Pera MF, Lansdorp PM: Stem cells: hype and reality. Hematology 2002: 369-391.

3 Wong RC, Pebay A: Signaling pathways involved in the maintenance of human embryonic stem cells. J Stem Cells 2006;1:271282.

4 Ohtsuka S, Dalton S: Molecular and biological properties of pluripotent embryonic stem cells. Gene Ther 2008;15:74-81.

$\checkmark 5$ Zhao C, Fancy SP, Magy L, Urwin JE, Franklin RJ: Stem cells, progenitors and myelin repair. J Anat 2005;207:251-258.
6 Picard-Riera N, Nait-Oumesmar B, BaronVan Evercooren A: Endogenous adult neural stem cells: limits and potential to repair the injured central nervous system. J Neurosci Res 2004;76:223-231.

7 van Meeteren LA, Ruurs P, Stortelers C, Bouwman P, van Rooijen MA, Pradere JP, Pettit TR, Wakelam MJ, Saulnier-Blache JS, Mummery CL, Moolenaar WH, Jonkers J: Autotaxin, a secreted lysophospholipase D, is essential for blood vessel formation during development. Mol Cell Biol 2006;26:50155022.
8 Aoki J: Mechanisms of lysophosphatidic acid production. Semin Cell Dev Biol 2004;15: 477-489.

-9 Bektas M, Payne SG, Liu H, Goparaju S, Milstien S, Spiegel S: A novel acylglycerol kinase that produces lysophosphatidic acid modulates cross talk with EGFR in prostate cancer cells. J Cell Biol 2005;169:801-811.

10 Dircks L, Sul HS: Acyltransferases of de novo glycerophospholipid biosynthesis. Prog Lipid Res 1999;38:461-479.

11 Pitson SM, Moretti PA, Zebol JR, Lynn HE, Xia P, Vadas MA, Wattenberg BW: Activation of sphingosine kinase 1 by ERK1/2-mediated phosphorylation. EMBO J 2003;22: 5491-5500. 
-12 Pitson SM, Xia P, Leclercq TM, Moretti PA, Zebol JR, Lynn HE, Wattenberg BW, Vadas MA: Phosphorylation-dependent translocation of sphingosine kinase to the plasma membrane drives its oncogenic signalling. J Exp Med 2005;201:49-54.

-13 Allende ML, Sasaki T, Kawai H, Olivera A, Mi Y, van Echten-Deckert G, Hajdu R, Rosenbach M, Keohane CA, Mandala S, Spiegel S, Proia RL: Mice deficient in sphingosine kinase 1 are rendered lymphopenic by FTY720. J Biol Chem 2004;279:5248752492.

-14 Mizugishi K, Yamashita T, Olivera A, Miller GF, Spiegel S, Proia RL: Essential role for sphingosine kinases in neural and vascular development. Mol Cell Biol 2005;25:1111311121.

-15 Yatomi Y, Ozaki Y, Ohmori T, Igarashi Y: Sphingosine 1-phosphate: synthesis and release. Prostaglandins Other Lipid Mediat 2001;64:107-122.

-16 Pappu R, Schwab SR, Cornelissen I, Pereira JP, Regard JB, Xu Y, Camerer E, Zheng YW, Huang Y, Cyster JG, Coughlin SR: Promotion of lymphocyte egress into blood and lymph by distinct sources of sphingosine-1phosphate. Science 2007;316:295-298.

-17 Venkataraman K, Lee YM, Michaud J, Thangada S, Ai Y, Bonkovsky HL, Parikh NS, Habrukowich C, Hla T: Vascular endothelium as a contributor of plasma sphingosine 1-phosphate. Circ Res 2008;102:669676.

-18 Mitra P, Oskeritzian CA, Payne SG, Beaven MA, Milstien S, Spiegel S: Role of ABCC1 in export of sphingosine-1-phosphate from mast cells. Proc Natl Acad Sci USA 2006;103: 16394-16399.

-19 Osborne N, Brand-Arzamendi K, Ober EA, Jin SW, Verkade H, Holtzman NG, Yelon D, Stainier DY: The spinster homolog, two of hearts, is required for sphingosine 1-phosphate signaling in zebrafish. Curr Biol 2008; 18:1882-1888.

-20 Kawahara A, Nishi T, Hisano Y, Fukui H, Yamaguchi A, Mochizuki N: The sphingolipid transporter spns2 functions in migration of zebrafish myocardial precursors. Science 2009;323:524-527.

-21 Ancellin N, Colmont C, Su J, Li Q, Mittereder N, Chae SS, Stefansson S, Liau G, Hla T: Extracellular export of sphingosine kinase-1 enzyme. Sphingosine 1-phosphate generation and the induction of angiogenic vascular maturation. J Biol Chem 2002;277:66676675 .

-22 Waters C, Sambi B, Kong KC, Thompson D, Pitson SM, Pyne S, Pyne NJ: Sphingosine 1phosphate and platelet-derived growth factor (PDGF) act via PDGF $\beta$ receptor-sphingosine 1-phosphate receptor complexes in airway smooth muscle cells. J Biol Chem 2003;278:6282-6290.
23 Soldi R, Mandinova A, Venkataraman K, Hla T, Vadas M, Pitson S, Duarte M, Graziani I, Kolev V, Kacer D, Kirov A, Maciag T, Prudovsky I: Sphingosine kinase 1 is a critical component of the copper-dependent FGF1 export pathway. Exp Cell Res 2007;313: 3308-3318.

24 Rosen H, Gonzalez-Cabrera PJ, Sanna MG, Brown S: Sphingosine 1-phosphate receptor signaling. Annu Rev Biochem 2009;78:743768.

25 Shimomura Y, Wajid M, Ishii Y, Shapiro L, Petukhova L, Gordon D, Christiano AM Disruption of p2ry5, an orphan G proteincoupled receptor, underlies autosomal recessive woolly hair. Nat Genet 2008;40:335339.

26 Pasternack SM, von Kugelgen I, Aboud KA, Lee YA, Ruschendorf F, Voss K, Hillmer AM Molderings GJ, Franz T, Ramirez A, Nurnberg P, Nothen MM, Betz RC: G protein-coupled receptor P2Y5 and its ligand LPA are involved in maintenance of human hair growth. Nat Genet 2008;40:329-334.

27 Yanagida K, Masago K, Nakanishi H, Kihara Y, Hamano F, Tajima Y, Taguchi R, Shimizu T, Ishii S: Identification and characterization of a novel lysophosphatidic acid receptor p2y5/LPA6. J Biol Chem 2009;284:1773117741.

28 Tabata K, Baba K, Shiraishi A, Ito M, Fujita $\mathrm{N}$ : The orphan GPCR GPR87 was deorphanized and shown to be a lysophosphatidic acid receptor. Biochem Biophys Res Commun 2007;363:861-866.

29 Murakami M, Shiraishi A, Tabata K, Fujita $\mathrm{N}$ : Identification of the orphan GPCR, P2 $\mathrm{Y}_{10}$ receptor as the sphingosine-1-phosphate and lysophosphatidic acid receptor. Biochem Biophys Res Commun 2008;371:707-712.

30 Pebay A, Bonder CS, Pitson SM: Stem cell regulation by lysophospholipids. Prostaglandins Other Lipid Mediat 2007;84:8397.

31 Meyer zu Heringdorf D, Jakobs KH: Lysophospholipid receptors: signalling, pharmacology and regulation by lysophospholipid metabolism. Biochim Biophys Acta 2007; 1768:923-940.

32 Tanimoto T, Lungu AO, Berk BC: Sphingosine 1-phosphate transactivates the plateletderived growth factor beta receptor and epidermal growth factor receptor in vascular smooth muscle cells. Circ Res 2004;94:1050 1058.

33 Sukocheva O, Wadham C, Holmes A, Albanese N, Verrier E, Feng F, Bernal A, Derian CK, Ullrich A, Vadas MA, Xia P: Estrogen transactivates EGFR via the sphingosine 1phosphate receptor EDG-3: the role of sphingosine kinase-1. J Cell Biol 2006;173:301310.
34 Shida D, Fang X, Kordula T, Takabe K, Lepine S, Alvarez SE, Milstien S, Spiegel S: Crosstalk between LPA1 and epidermal growth factor receptors mediates up-regulation of sphingosine kinase 1 to promote gastric cancer cell motility and invasion. Cancer Res 2008;68:6569-6577.

35 Lebman DA, Spiegel S: Cross-talk at the crossroads of sphingosine-1-phosphate, growth factors, and cytokine signaling. J Lipid Res 2008;49:1388-1394.

36 McIntyre TM, Pontsler AV, Silva AR, St Hilaire A, Xu Y, Hinshaw JC, Zimmerman GA, Hama K, Aoki J, Arai H, Prestwich GD: Identification of an intracellular receptor for lysophosphatidic acid (LPA): LPA is a transcellular PPAR $y$ agonist. Proc Natl Acad Sci USA 2003;100:131-136.

37 Lehrke M, Lazar MA: The many faces of PPAR $\gamma$. Cell 2005;123:993-999.

-38 Lee CW, Rivera R, Gardell S, Dubin AE, Chun J: Gpr92 as a new $\mathrm{G}_{12 / 13^{-}}$and $\mathrm{G}_{\mathrm{q}^{-}}$-coupled lysophosphatidic acid receptor that increases cAMP, LPA 5 . J Biol Chem 2006;281: 23589-23597.

39 Kleger A, Busch T, Liebau S, Prelle K, Paschke S, Beil M, Rolletschek A, Wobus A, Wolf E, Adler G, Seufferlein T: The bioactive lipid sphingosylphosphorylcholine induces differentiation of mouse embryonic stem cells and human promyelocytic leukaemia cells. Cell Signal 2007;19:367-377.

40 Rodgers A, Mormeneo D, Long JS, Delgado A, Pyne NJ, Pyne S: Sphingosine 1-phosphate regulation of extracellular signal regulated kinase-1/2 in embyronic stem cells. Stem Cells Dev 2009; Epub ahead of print.

41 Todorova MG, Fuentes E, Soria B, Nadal A, Quesada I: Lysophosphatidic acid induces $\mathrm{Ca} 2+$ mobilization and $\mathrm{c}-\mathrm{Myc}$ expression in mouse embryonic stem cells via the phospholipase C pathway. Cell Signal 2009;21: 523-528.

42 Burdon T, Smith A, Savatier P: Signalling, cell cycle and pluripotency in embryonic stem cells. Trends Cell Biol 2002;12:432438.

43 Choi HJ, Lee JH, Park SY, Cho JH, Han JS: STAT3 is involved in phosphatidic acid-induced Bcl-2 expression in HeLa cells. Exp Mol Med 2009;41:94-101.

44 Frias MA, James RW, Gerber-Wicht C, Lang $\mathrm{U}$ : Native and reconstituted HDL activate Stat3 in ventricular cardiomyocytes via ERK1/2: role of sphingosine-1-phosphate. Cardiovasc Res 2009;82:313-323.

45 Schuck S, Soloaga A, Schratt G, Arthur JS, Nordheim A: The kinase MSK1 is required for induction of $\mathrm{c}$-fos by lysophosphatidic acid in mouse embryonic stem cells. BMC Mol Biol 2003;4:6.

46 Burdon T, Stracey C, Chambers I, Nichols J, Smith A: Suppression of SHP-2 and ERK signalling promotes self-renewal of mouse embryonic stem cells. Dev Biol 1999;210:3043. 
-47 Sachinidis A, Gissel C, Nierhoff D, HipplerAltenburg R, Sauer H, Wartenberg M, Hescheler J: Identification of platelet-derived growth factor-BB as cardiogenesis-inducing factor in mouse embryonic stem cells under serum-free conditions. Cell Physiol Biochem 2003;13:423-429.

-48 Bieberich E, MacKinnon S, Silva J, Noggle S, Condie BG: Regulation of cell death in mitotic neural progenitor cells by asymmetric distribution of prostate apoptosis response 4 (PAR-4) and simultaneous elevation of endogenous ceramide. J Cell Biol 2003;162: 469-479.

-49 Cuvillier O, Pirianov G, Kleuser B, Vanek PG, Coso OA, Gutkind S, Spiegel S: Suppression of ceramide-mediated programmed cell death by sphingosine-1-phosphate. Nature 1996;381:800-803.

50 Bieberich E: Smart drugs for smarter stem cells: making sense (sphingolipid-enhanced neural stem cells) of ceramide. Neurosignals 2008;16:124-139.

51 Bieberich E, Silva J, Wang G, Krishnamurthy $\mathrm{K}$, Condie BG: Selective apoptosis of pluripotent mouse and human stem cells by novel ceramide analogues prevents teratoma formation and enriches for neural precursors in ES cell-derived neural transplants. J Cell Biol 2004; 167:723-734.

- 52 Brimble SN, Sherrer ES, Uhl EW, Wang E, Kelly S, Merrill AH Jr, Robins AJ, Schulz TC: The cell surface glycosphingolipids SSEA-3 and SSEA- 4 are not essential for human ESC pluripotency. Stem Cells 2007;25:54-62.

53 Pebay A, Wong RC, Pitson SM, Wolvetang EJ, Peh GS, Filipczyk A, Koh KL, Tellis I, Nguyen LT, Pera MF: Essential roles of sphingosine-1-phosphate and platelet-derived growth factor in the maintenance of human embryonic stem cells. Stem Cells 2005;23: 1541-1548.

54 Inniss K, Moore H: Mediation of apoptosis and proliferation of human embryonic stem cells by sphingosine-1-phosphate. Stem Cells Dev 2006;15:789-796.

-55 Dottori M, Leung J, Turnley AM, Pebay A: Lysophosphatidic acid inhibits neuronal differentiation of neural stem/progenitor cells derived from human embryonic stem cells. Stem Cells 2008;26:1146-1154.

56 Wong RC, Tellis I, Jamshidi P, Pera M, Pebay A: Anti-apoptotic effect of sphingosine-1phosphate and platelet-derived growth factor in human embryonic stem cells. Stem Cells Dev 2007;16:989-1001.

- 57 Avery K, Avery S, Shepherd J, Heath PR, Moore H: Sphingosine-1-phosphate mediates transcriptional regulation of key targets associated with survival, proliferation, and pluripotency in human embryonic stem cells. Stem Cells Dev 2008;17:1195-1205.

- 58 James D, Levine AJ, Besser D, HemmatiBrivanlou A: TGFbeta/activin/nodal signaling is necessary for the maintenance of pluripotency in human embryonic stem cells. Development 2005;132:1273-1282.
59 Garcia-Gonzalo FR, Belmonte JC: Albuminassociated lipids regulate human embryonic stem cell self-renewal. PLoS One 2008;3: e1384.

60 Salli U, Fox TE, Carkaci-Salli N, Sharma A, Robertson GP, Kester M, Vrana K: Propagation of undifferentiated human embryonic stem cells with nano-liposomal ceramide. Stem Cells Dev 2008; Epub ahead of print.

61 Takahashi K, Yamanaka S: Induction of pluripotent stem cells from mouse embryonic and adult fibroblast cultures by defined factors. Cell 2006;126:663-676.

62 Okita K, Ichisaka T, Yamanaka S: Generation of germline-competent induced pluripotent stem cells. Nature 2007;448:313-317.

63 Park IH, Zhao R, West JA, Yabuuchi A, Huo $\mathrm{H}$, Ince TA, Lerou PH, Lensch MW, Daley GQ: Reprogramming of human somatic cells to pluripotency with defined factors. Nature 2008;451:141-146.

64 Takahashi K, Tanabe K, Ohnuki M, Narita M, Ichisaka T, Tomoda K, Yamanaka S: Induction of pluripotent stem cells from adult human fibroblasts by defined factors. Cell 2007;131:861-872.

65 Yu J, Vodyanik MA, Smuga-Otto K, Antosiewicz-Bourget J, Frane JL, Tian S, Nie J, Jonsdottir GA, Ruotti V, Stewart R, Slukvin II, Thomson JA: Induced pluripotent stem cell lines derived from human somatic cells. Science 2007;318:1917-1920.

-66 Nakagawa M, Koyanagi M, Tanabe K, Takahashi K, Ichisaka T, Aoi T, Okita K, Mochiduki Y, Takizawa N, Yamanaka S: Generation of induced pluripotent stem cells without Myc from mouse and human fibroblasts. Nat Biotechnol 2008;26:101-106.

67 Harada J, Foley M, Moskowitz MA, Waeber C: Sphingosine-1-phosphate induces proliferation and morphological changes of neural progenitor cells. J Neurochem 2004;88: 1026-1039.

68 Rhee HJ, Nam JS, Sun Y, Kim MJ, Choi HK, Han DH, Kim NH, Huh SO: Lysophosphatidic acid stimulates cAMP accumulation and cAMP response element-binding protein phosphorylation in immortalized hippocampal progenitor cells. Neuroreport 2006; 17:523-526.

69 Kimura A, Ohmori T, Ohkawa R, Madoiwa S, Mimuro J, Murakami T, Kobayashi E, Hoshino Y, Yatomi Y, Sakata Y: Essential roles of sphingosine 1-phosphate/S1P1 receptor axis in the migration of neural stem cells toward a site of spinal cord injury. Stem Cells 2007;25:115-124.

70 Kimura A, Ohmori T, Kashiwakura Y, Ohkawa R, Madoiwa S, Mimuro J, Shimazaki K, Hoshino Y, Yatomi Y, Sakata Y: Antagonism of sphingosine 1-phosphate receptor-2 enhances migration of neural progenitor cells toward an area of brain. Stroke 2008;39: 3411-3417.
71 Svetlov SI, Ignatova TN, Wang KK, Hayes RL, English D, Kukekov VG: Lysophosphatidic acid induces clonal generation of mouse neurospheres via proliferation of Sca-1- and AC133-positive neural progenitors. Stem Cells Dev 2004;13:685-693.

72 Shin S, Mitalipova M, Noggle S, Tibbitts D, Venable A, Rao R, Stice SL: Long-term proliferation of human embryonic stem cell-derived neuroepithelial cells using defined adherent culture conditions. Stem Cells 2006; 24:125-138.

73 Hurst JH, Mumaw J, Machacek DW, Sturkie C, Callihan P, Stice SL, Hooks SB: Human neural progenitors express functional lysophospholipid receptors that regulate cell growth and morphology. BMC Neurosci 2008;9:118.

74 Lee CW, Rivera R, Dubin AE, Chun J: LPA $/$ GPR23 is a lysophosphatidic acid (LPA) receptor utilizing $\mathrm{G}_{\mathrm{s}^{-}}, \mathrm{G}_{\mathrm{q}} / \mathrm{G}_{\mathrm{i}^{-}}$-mediated calcium signaling and $\mathrm{G}_{12 / 13}$-mediated Rho activation. J Biol Chem 2007;282:4310-4317.

75 Noguchi K, Ishii S, Shimizu T: Identification of 2 y9/GPR23 as a novel G protein-coupled receptor for lysophosphatidic acid, structurally distant from the Edg family. J Biol Chem 2003;278:25600-25606.

76 Dawson J, Hotchin N, Lax S, Rumsby M: Lysophosphatidic acid induces process retraction in CG-4 line oligodendrocytes and oligodendrocyte precursor cells but not in differentiated oligodendrocytes. J Neurochem 2003;87:947-957.

77 Jaillard C, Harrison S, Stankoff B, Aigrot MS, Calver AR, Duddy G, Walsh FS, Pangalos MN, Arimura N, Kaibuchi K, Zalc B, Lubetzki C: Edg8/S1P5: an oligodendroglial receptor with dual function on process retraction and cell survival. J Neurosci 2005; 25:1459-1469.

78 Novgorodov AS, El-Alwani M, Bielawski J, Obeid LM, Gudz TI: Activation of sphingosine-1-phosphate receptor S1P5 inhibits oligodendrocyte progenitor migration. FASEB J 2007;21:1503-1514.

79 Terai K, Soga T, Takahashi M, Kamohara M, Ohno K, Yatsugi S, Okada M, Yamaguchi T: Edg-8 receptors are preferentially expressed in oligodendrocyte lineage cells of the rat CNS. Neuroscience 2003;116:1053-1062.

80 Miron VE, Jung CG, Kim HJ, Kennedy TE, Soliven B, Antel JP: FTY720 modulates human oligodendrocyte progenitor process extension and survival. Ann Neurol 2008;63: 61-71.

81 Moller T, Contos JJ, Musante DB, Chun J, Ransom BR: Expression and function of lysophosphatidic acid receptors in cultured rodent microglial cells. J Biol Chem 2001; 276:25946-25952.

82 Tham CS, Lin FF, Rao TS, Yu N, Webb M: Microglial activation state and lysophospholipid acid receptor expression. Int J Dev Neurosci 2003;21:431-443. 
83 Pebay A, Torrens Y, Toutant M, Cordier J, Glowinski J, Tence M: Pleiotropic effects of lysophosphatidic acid on striatal astrocytes. Glia 1999;28:25-33.

-84 Pebay A, Toutant M, Premont J, Calvo CF, Venance L, Cordier J, Glowinski J, Tence M: Sphingosine-1-phosphate induces proliferation of astrocytes: regulation by intracellular signalling cascades. Eur J Neurosci 2001;13: 2067-2076

-85 Rouach N, Pebay A, Meme W, Cordier J, Ezan P, Etienne E, Giaume C, Tence M: S1P inhibits gap junctions in astrocytes: involvement of G and Rho GTPase/ROCK. Eur J Neurosci 2006;23:1453-1464.

86 Keller JN, Steiner MR, Mattson MP, Steiner SM: Lysophosphatidic acid decreases glutamate and glucose uptake by astrocytes. J Neurochem 1996;67:2300-2305.

-87 Keller JN, Steiner MR, Holtsberg FW, Mattson MP, Steiner SM: Lysophosphatidic acidinduced proliferation-related signals in astrocytes. J Neurochem 1997;69:1073-1084.

88 Weiner JA, Hecht JH, Chun J: Lysophosphatidic acid receptor gene vzg-1/lpA1/edg-2 is expressed by mature oligodendrocytes during myelination in the postnatal murine brain. J Comp Neurol 1998;398:587-598.

89 Li Y, Gonzalez MI, Meinkoth JL, Field J, Kazanietz MG, Tennekoon GI: Lysophosphatidic acid promotes survival and differentiation of rat Schwann cells. J Biol Chem 2003; 278:9585-9591.

90 Jalink K, Eichholtz T, Postma FR, van Corven EJ, Moolenaar WH: Lysophosphatidic acid induces neuronal shape changes via a novel, receptor-mediated signaling pathway: similarity to thrombin action. Cell Growth Differ 1993;4:247-255.

91 Fukushima N: LPA in neural cell development. J Cell Biochem 2004;92:993-1003.

92 Kingsbury MA, Rehen SK, Contos JJ, Higgins CM, Chun J: Non-proliferative effects of lysophosphatidic acid enhance cortical growth and folding. Nat Neurosci 2003;6: 1292-1299.

93 Fukushima N, Shano S, Moriyama R, Chun J: Lysophosphatidic acid stimulates neuronal differentiation of cortical neuroblasts through the LPA1-G(i/o) pathway. Neurochem Int 2007;50:302-307.

94 Saini HS, Coelho RP, Goparaju SK, Jolly PS, Maceyka M, Spiegel S, Sato-Bigbee C: Novel role of sphingosine kinase 1 as a mediator of neurotrophin-3 action in oligodendrocyte progenitors. J Neurochem 2005;95:1298-1310.

95 Fukushima N, Weiner JA, Chun J: Lysophosphatidic acid (LPA) is a novel extracellular regulator of cortical neuroblast morphology. Dev Biol 2000;228:6-18.

-96 Kingsbury MA, Rehen SK, Ye X, Chun J: Genetics and cell biology of lysophosphatidic acid receptor-mediated signaling during cortical neurogenesis. J Cell Biochem 2004; 92:1004-1012.
-97 Bassi R, Anelli V, Giussani P, Tettamanti G, Viani P, Riboni L: Sphingosine-1-phosphate is released by cerebellar astrocytes in response to bFGF and induces astrocyte proliferation through Gi-protein-coupled receptors. Glia 2006;53:621-630.

$\$ 98$ Contos JJ, Fukushima N, Weiner JA, Kaushal D, Chun J: Requirement for the lpA1 lysophosphatidic acid receptor gene in normal suckling behavior. Proc Natl Acad Sci USA 2000;97:13384-13389.

\$9 Hecht JH, Weiner JA, Post SR, Chun J: Ventricular zone gene-1 (vzg-1) encodes a lysophosphatidic acid receptor expressed in neurogenic regions of the developing cerebral cortex. J Cell Biol 1996;135:10711083.

100 Dubin AE, Bahnson T, Weiner JA, Fukushima N, Chun J: Lysophosphatidic acid stimulates neurotransmitter-like conductance changes that precede GABA and Lglutamate in early, presumptive cortical neuroblasts. J Neurosci 1999;19:13711381.

101 Reynolds BA, Rietze RL: Neural stem cells and neurospheres - re-evaluating the relationship. Nat Methods 2005;2:333-336.

102 Reynolds BA, Weiss S: Generation of neurons and astrocytes from isolated cells of the adult mammalian central nervous system. Science 1992;255:1707-1710.

103 Cui HL, Qiao JT: Promotive action of lysophosphatidic acid on proliferation of rat embryonic neural stem cells and their differentiation to cholinergic neurons in vitro. Sheng Li Xue Bao 2006;58:547-555.

104 Baumann N, Pham-Dinh D: Biology of oligodendrocyte and myelin in the mammalian central nervous system. Physiol Rev 2001;81:871-927.

105 Miron VE, Hall JA, Kennedy TE, Soliven B, Antel JP: Cyclical and dose-dependent responses of adult human mature oligodendrocytes to fingolimod. Am J Pathol 2008; 173:1143-1152.

106 Coelho RP, Payne SG, Bittman R, Spiegel S, Sato-Bigbee C: The immunomodulator FTY720 has a direct cytoprotective effect in oligodendrocyte progenitors. J Pharmacol Exp Ther 2007;323:626-635.

107 Saini HS, Gorse KM, Boxer LM, Sato-Bigbee C: Neurotrophin-3 and a CREB-mediated signaling pathway regulate $\mathrm{Bcl}-2 \mathrm{ex}-$ pression in oligodendrocyte progenitor cells. J Neurochem 2004;89:951-961.

108 Bieberich E, MacKinnon S, Silva J, Yu RK: Regulation of apoptosis during neuronal differentiation by ceramide and b-series complex gangliosides. J Biol Chem 2001; 276:44396-44404.

109 Wang G, Krishnamurthy K, Chiang YW, Dasgupta S, Bieberich E: Regulation of neural progenitor cell motility by ceramide and potential implications for mouse brain development. J Neurochem 2008;106:718733.
110 Bieberich E: Ceramide signaling in cancer and stem cells. Future Lipidol 2008;3:273300.

111 Steiner MR, Urso JR, Klein J, Steiner SM: Multiple astrocyte responses to lysophosphatidic acids. Biochim Biophys Acta 2002; 1582:154-160.

112 Eichholtz T, Jalink K, Fahrenfort I, Moolenaar WH: The bioactive phospholipid lysophosphatidic acid is released from activated platelets. Biochem J 1993;291:677-680.

113 Tigyi G, Hong L, Yakubu M, Parfenova H, Shibata M, Leffler CW: Lysophosphatidic acid alters cerebrovascular reactivity in piglets. Am J Physiol 1995;268:H2048-H2055.

- 114 Savaskan NE, Rocha L, Kotter MR, Baer A, Lubec G, van Meeteren LA, Kishi Y, Aoki J, Moolenaar WH, Nitsch R, Brauer AU: Autotaxin (NPP-2) in the brain: Cell type-specific expression and regulation during development and after neurotrauma. Cell Mol Life Sci 2007;64:230-243.

115 Sorensen SD, Nicole O, Peavy RD, Montoya LM, Lee CJ, Murphy TJ, Traynelis SF, Hepler JR: Common signaling pathways link activation of murine PAR-1, LPA, and S1P receptors to proliferation of astrocytes. Mol Pharmacol 2003;64:1199-1209.

116 Elmes SJ, Millns PJ, Smart D, Kendall DA, Chapman V: Evidence for biological effects of exogenous LPA on rat primary afferent and spinal cord neurons. Brain Res 2004; 1022:205-213.

117 Fujita R, Kiguchi N, Ueda H: LPA-mediated demyelination in ex vivo culture of dorsal root. Neurochem Int 2007;50:351-355.

118 Ueda H: Molecular mechanisms of neuropathic pain-phenotypic switch and initiation mechanisms. Pharmacol Ther 2006; 109:57-77.

119 Renback K, Inoue M, Ueda H: Lysophosphatidic acid-induced, pertussis toxin-sensitive nociception through a substance $\mathrm{P}$ release from peripheral nerve endings in mice. Neurosci Lett 1999;270:59-61.

120 Renback K, Inoue M, Yoshida A, Nyberg F, Ueda H: Vzg-1/lysophosphatidic acid-receptor involved in peripheral pain transmission. Brain Res Mol Brain Res 2000;75: 350-354.

121 Inoue M, Rashid MH, Fujita R, Contos JJ, Chun J, Ueda H: Initiation of neuropathic pain requires lysophosphatidic acid receptor signaling. Nat Med 2004;10:712-718.

122 Holtsberg FW, Steiner MR, Keller JN, Mark RJ, Mattson MP, Steiner SM: Lysophosphatidic acid induces necrosis and apoptosis in hippocampal neurons. J Neurochem 1998; 70:66-76.

123 Brault S, Gobeil F Jr, Fortier A, Honore JC, Joyal JS, Sapieha PS, Kooli A, Martin E, Hardy P, Ribeiro-da-Silva A, Peri K, Lachapelle P, Varma D, Chemtob S: Lysophosphatidic acid induces endothelial cell death by modulating the redox environment. Am J Physiol Regul Integr Comp Physiol 2007; 292:R1174-R1183. 
124 Edsall LC, Spiegel S: Enzymatic measurement of sphingosine 1-phosphate. Anal Biochem 1999;272:80-86.

125 Annabi B, Lachambre MP, Plouffe K, Sartelet H, Béliveau R: Modulation of invasive properties of CD133(+) glioblastoma stem cells: a role for MT1-mmp in bioactive lysophospholipid signaling. Mol Carcinog 2009; Epub ahead of print.

126 Liu G, Yuan X, Zeng Z, Tunici P, Ng H, Abdulkadir IR, Lu L, Irvin D, Black KL, Yu JS: Analysis of gene expression and chemoresistance of CD133+ cancer stem cells in glioblastoma. Mol Cancer 2006;5:67.

127 Van Brocklyn JR, Jackson CA, Pearl DK, Kotur MS, Snyder PJ, Prior TW: Sphingosine kinase-1 expression correlates with poor survival of patients with glioblastoma multiforme: roles of sphingosine kinase isoforms in growth of glioblastoma cell lines. J Neuropathol Exp Neurol 2005;64: 695-705.
128 Hoelzinger DB, Mariani L, Weis J, Woyke T, Berens TJ, McDonough WS, Sloan A Coons SW, Berens ME: Gene expression profile of glioblastoma multiforme invasive phenotype points to new therapeutic targets. Neoplasia 2005;7:7-16.

129 Kishi Y, Okudaira S, Tanaka M, Hama K, Shida D, Kitayama J, Yamori T, Aoki J, Fujimaki T, Arai H: Autotaxin is overexpressed in glioblastoma multiforme and contributes to cell motility of glioblastoma by converting lysophosphatidylcholine to lysophosphatidic acid. J Biol Chem 2006; 281:17492-17500.

130 Li J, Guan HY, Gong LY, Song LB, Zhang N, Wu J, Yuan J, Zheng YJ, Huang ZS, Li M Clinical significance of sphingosine kinase-1 expression in human astrocytomas progression and overall patient survival. Clin Cancer Res 2008;14:6996-7003.
131 Paugh BS, Bryan L, Paugh SW, Wilczynska KM, Alvarez SM, Singh SK, Kapitonov D, Rokita H, Wright S, Griswold-Prenner I, Milstien S, Spiegel S, Kordula T: Interleukin-1 regulates the expression of sphingosine kinase 1 in glioblastoma cells. J Biol Chem 2009;284:3408-3417.

132 Hoelzinger DB, Nakada M, Demuth T, Rosensteel T, Reavie LB, Berens ME: Autotaxin: a secreted autocrine/paracrine factor that promotes glioma invasion. J Neurooncol 2008;86:297-309.

133 Gaetano CG, Samadi N, Tomsig JL, Macdonald TL, Lynch KR, Brindley DN: Inhibition of autotaxin production or activity blocks lysophosphatidylcholine-induced migration of human breast cancer and melanoma cells. Mol Carcinog 2009; Epub ahead of print. 